\title{
Defined Criterion Group Composition Relationship Sequence Number
}

National Cancer Institute

\section{Source}

National Cancer Institute. Defined Criterion Group Composition Relationship Sequence

Number. NCl Thesaurus. Code $C 93765$.

An integer specifying the relative sequential or temporal ordering of this relationship among other similar relationships having the same source. 